\title{
CHANGES OF LAND USE MONITORING WITHIN FOREST AREA
}

\section{Cherie Bhekti Pribadi ${ }^{1}$, Teguh Hariyanto ${ }^{2}$, Akbar Kurniawan ${ }^{3}$, Yessherly Amriana ${ }^{4}$}

1,2,3,4 Departemen Teknik Geomatika, FTSLK-ITS, Kampus ITS Sukolilo, Surabaya, 60111, Indonesia e-mail: ${ }^{1}$ cheriebhekti@gmail.com, ${ }^{2}$ tgh_hary@yahoo.com, ${ }^{3}$ akbar.geodesy@gmail.com, ${ }^{4}$ yessherly@gmail.com

\begin{abstract}
Pasrujambe District is one of sub-districts in Lumajang Regency which has a forest area. Forests are main source of life for people who live in surrounding villages, start from farming, logging, taking firewood, gathering, and grazing their livestock in forest areas. This phenomenon cannot be avoided from use of forest land for the other land functions, both for settlements, agriculture and other regions. Therefore, it's needed to be related to changes of land use in forest areas. In this study an evaluation of distribution and extent of land use functions in Pasrujambe District forest area was carried out using 2 (two) methods, namely object-based classification methods and interpretation methods (digitized on screen). The results show us that there are changes of land use in forest areas in 2017, such as industries, plantations, agricultures, plantations, bushes and settlements with total area of $3764.38 \mathrm{Ha}$ and for agricultural land use such as lakes, grasslands and rivers with total area of 799.41 ha
\end{abstract}

Keywords: Pasrujambe District, Forests, Land use changes. 


\section{INTRODUCTION}

Lumajang Regency consists of 21 sub-districts with area of $179,090 \mathrm{Ha}$ which has a forest area of 59,462 Ha (BPS East Java Province 2016). Overall the state forest area in Lumajang Regency is a highland area, one of which is located in Pasrujambe District, where subdistrict is divided into 7 villages. The forest area in sub-district is controlled and managed by Head of the Lumajang Forest Stakeholder Unit, which is under Probolinggo Forest Management Unit, East Java. Forests are main source of life for residents living in surrounding villages, start from farming, cutting wood for household utensils, taking firewood, collecting grass / leaves for animal feed, and grazing their livestock in forest areas. Land use is determined by the interaction in space and time of biophysical factors (constraints) such as soils, climate, topography, etc (Agarwal, et.al., 2000). This phenomenon cannot be avoided from use of forest land for the other land functions, both for settlements, agriculture and other areas. Therefore, there is need for monitoring of changes in land use within forest area.

Identification of land use within forest area is very important to do to find out whether the land use carried out by human activities which is appropriate or actually violates the boundaries of the forest area. This is very influential on sustainability of the function of forest itself. Identification of land use functions to find out how much land use changes occur from year to year. In this study an evaluation of changes in land use within forest area in Pasrujambe District is carried out by utilizing remote sensing technology and Geographic Information System (GIS). Image depends on spatial resolution and on radiometric resolution of the optical instrument (Lilesand \& Kiefer, 1976).

The evaluation using 2 (two) methods, such as object-based classification methods and interpretation methods (digitized on screen). Object-based classification method is chosen because these method has advantage in term of analysis of classification of high-resolution satellite images compared to pixel-based classification method (Zhang \& Maxwell, 2006). Interpretation methods (digitized on screen) are carried out through the digitization of land use classes in the Pasrujambe District forest area, where two methods can evaluate changes in land use utilization in 2009 (assets) and 2016 (liabilities) within forest area so it can provide information about description of initial state of change that occurred and final state of a forest resource in Pasrujambe District.

\section{DATA AND STUDY AREAS}

The location of this research was conducted in Pasrujambe District, Lumajang, East Java. This area is geographically located between $88^{\circ} 5^{\prime} 2.04^{\prime \prime}$ South Latitude and $112^{\circ} 58^{\prime} 38.53^{\prime \prime}$ East Longitude.

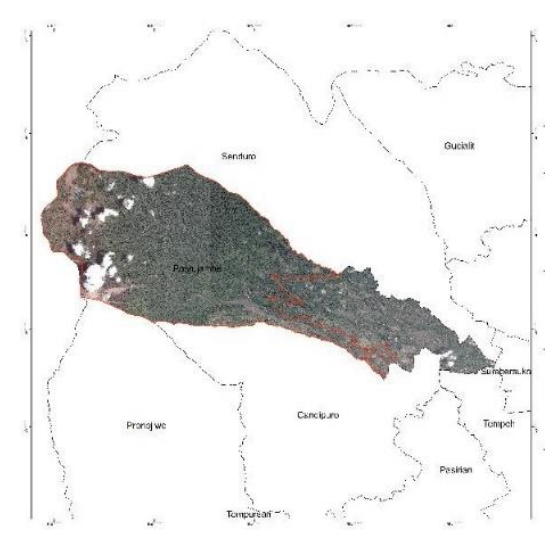

Figure 1. Research Area

The data used in this research, among others:

a. High Resolution Satellite Imagery Pleiades 1-A 2016 orthorectified with spatial resolution of 0.5 meters.

b. Land Use in Pasrujambe District in year 2009

c. The Forest Zone of Lumajang Regency in year 2017

d. Administrative Border of Pasrujambe Subdistrict, Lumajang Regency, East Java

\section{METHOD}

Data processing methods in this study as follows :

a. Subsetting Image Area

It is used to focus more on data processing in accordance with research case studies.

b. Object-Based Classification Image Segmentation is an initial step in image classification with an object-based method that aims to group pixels into homogeneous regions based on certain similarity criteria between gray level of a pixel and gray level of neighboring pixels. Merging of Classification Results, aims to combine the classification results that have same land use class. Smoothing Classification Results aims to smooth classification polygons 
that were previously raster or pixel type files. Land Use of Object-Based Classification is result of object-based classification methods that are processed using eCognition software. Multiresolution segmentation is one basic procedure in the software eCognition for object-oriented image analysis. It is used here to produce image object primitives as a first step for a further classification and other processing procedures. As a part of the betaversion of eCognition multiresolution segmentation was successfully applied to many different problems in the fields of remote sensing (Baatz \& Schape, 2000).

c. Interpretation (digitized on screen)

It is the process to convert geographical objects from raster to vector map data (vectorization) based on the ability of an interpreter. In this study, it is digitized on screen directly on computer monitor. If the digitization process is complete, land use will be produced using the interpretation method (digitized on screen). The interpreter uses patterns, tones, textures, shapes, and site associations to derive information about land use activities from what is basically information about land cover (Anderson, et.al., 1976).

d. Classification Accuracy Test

In stages of accuracy test of land use classification based on object-based classification and interpretation (digitized on screen), each level of accuracy will be tested by confussion matrix using groundtruth ROI. The value of accuracy is a minimum value of $85 \%$ or 0.85 . If the results of classification don't meet the minimum value of accuracy test, it will return to stages of image segmentation, until the classification results that meet the minimum test of accuracy are obtained (Anderson, et.al., 1976).

\section{RESULTS AND DISCUSSION}

\section{Evaluation of Distribution and Area of Land Use Functions}

Evaluation of distribution and area of land use functions in forest areas can be carried out if there are different land uses for 2 years in a long period of time, for example more than 5 years. Long intervals are chosen so changes in distribution and area can be seen significantly. In this study an evaluation of distribution and area of land use functions in 2009 and 2016 will be carried out in Pasrujambe District Forest Area, Lumajang Regency by applying Geographic Information System (GIS) technology. Geographic information systems have emerged in the last decade as an essential tool for urban and resource planning and management (Demers, 1997). Land use in 2016 used in evaluating distribution and area of land use in this study, such as land use using object-based classification methods. Table 1 describe us about results of the area of land use in 2009 in Pasrujambe District forest area.

Table 1. Land Use Area in Year 2009

\begin{tabular}{clcc}
\hline No. & \multicolumn{1}{c}{ Land Use } & Area (Ha) & Percentage (\%) \\
\hline 1 & Lake & 29.27 & 0.24 \\
2 & Forest & 7263.27 & 58.60 \\
3 & Grassland & 342.58 & 2.76 \\
4 & Plantations & 947.36 & 7.64 \\
5 & Settlement & 78.92 & 0.64 \\
6 & Rainfed Rice Field & 721.91 & 5.82 \\
7 & Shrubs & 2734.35 & 22.06 \\
8 & River & 235.97 & 1.90 \\
9 & Moor & 41.27 & 0.33 \\
& Total & $\mathbf{1 2 3 9 4 , 9 1}$ & $\mathbf{1 0 0}$ \\
\hline
\end{tabular}

While the results of the land use area in 2017 in forest area as a result of object-based classification are presented in Table 2 .

Table 2. Land Use Area in Year 2017

\begin{tabular}{|c|c|c|c|}
\hline No. & Land Use & Area (Ha) & $\begin{array}{c}\text { Percentage } \\
(\%)\end{array}$ \\
\hline 1 & Lake & 28,77 & 0.23 \\
\hline 2 & Forest & 7831,12 & 63.18 \\
\hline 3 & Industry & 0,80 & 0.01 \\
\hline 4 & Grassland & 556,57 & 4.49 \\
\hline 5 & Plantations & 571,22 & 4.61 \\
\hline 6 & Settlement & 63,50 & 0.51 \\
\hline 7 & Irrigated Rice Field & 182,16 & 1.47 \\
\hline 8 & Rainfed Rice Field & 739,95 & 5.97 \\
\hline 9 & Shrubs & 1890,01 & 15.25 \\
\hline 10 & River & 214,07 & 1.73 \\
\hline 11 & Moor & 316,74 & 2.56 \\
\hline \multicolumn{2}{|r|}{ Total } & 12394,90 & 100 \\
\hline
\end{tabular}

Evaluation of the distribution and area of land use in the Pasrujambe District Forest area was made to compile a forest resource balance in Pasrujambe District. From both land use area in year 2009 and year 2016 can be seen that forest resource reserve and amount of forest resource utilization has been carried out in the area. 


\section{Forest Resource Balance Results}

a. Assets of Forest Resources in 2009 Amount of initial forest resource reserves state in assets. The Results of assets of forest resources in this study use land use in 2009 in Pasrujambe District forest area can be seen in Table 3.

Table 3. Assets of Forest Resources in Year 2009

\begin{tabular}{llccccc}
\hline No & $\begin{array}{c}\text { Land Use in } \\
\text { Year } \\
\mathbf{2 0 0 9}\end{array}$ & $\begin{array}{c}\text { Protected } \\
\text { Forest } \\
\text { (ha) }\end{array}$ & $\begin{array}{c}\text { Production } \\
\text { Forest } \\
\text { (ha) }\end{array}$ & $\begin{array}{c}\text { National } \\
\text { Park } \\
\text { (ha) }\end{array}$ & $\begin{array}{c}\text { Forest Zone } \\
\text { (ha) }\end{array}$ & $\begin{array}{c}\text { Percentage } \\
\text { (\%) }\end{array}$ \\
\hline 1 & Lake & 0.00 & 0.00 & 29.27 & 29.27 & 0.24 \\
2 & Forest & 157.31 & 1054.75 & 6051.19 & 7263.26 & 58.60 \\
3 & Grassland & 0.00 & 1.83 & 340.75 & 342.58 & 2.76 \\
4 & Plantation & 23.63 & 882.52 & 41.21 & 947.36 & 7.64 \\
5 & Settlement & 0.00 & 78.92 & 0.00 & 78.92 & 0.64 \\
& Rainfed Rice & & & & & \\
6 & Field & 0.00 & 721.91 & 0.00 & 721.91 & 5.82 \\
7 & Shrubs & 5.41 & 139.82 & 2589.12 & 2734.35 & 22.06 \\
8 & River & 0.00 & 185.42 & 50.55 & 235.97 & 1.90 \\
9 & Moor & 0.00 & 41.27 & 0.00 & 41.27 & 0.33 \\
& Total & $\mathbf{1 8 6 . 3 5}$ & $\mathbf{3 1 0 6 . 4 5}$ & $\mathbf{9 1 0 2 . 0 9}$ & $\mathbf{1 2 3 9 4 . 9 0}$ & $\mathbf{1 0 0}$ \\
\hline
\end{tabular}

Based on its function or status, forest area in Pasrujambe District consists of various regions, such as protected forest, production forest and national park. Land use in year 2009 (assets) in forest area of Pasrujambe District was dominated by natural land use, such as shrubs and plantations. The proportion of land use assets in 2009 in largest forest area in shrubs of $2734.35 \mathrm{Ha} \mathrm{(22 \% )}$ and smallest area on moor of $41.27 \mathrm{Ha}(0.33 \%)$. The proportion of forest area is $7263.26 \mathrm{Ha}(58.60 \%)$ of the total area.

In year 2009, the most people who lived in the forest area of the Pasrujambe District had a livelihood as farmers. It is indicated that the coverage of agricultural areas is quite extensive, which consists of plantations and rice fields.

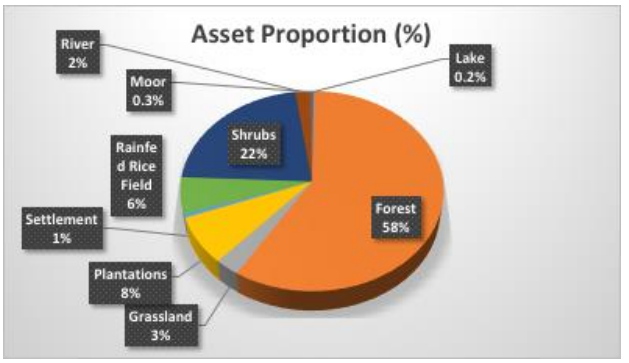

Figure 2. Assets Proportion of Forest Resources in Pasrujambe District in Year 2009
Figure 3 below is map of assets of forest resources made based on land use in year 2009 which is consist of 9 classes, such as lakes, forests, fields, plantations, settlements, rice fields, fountains.

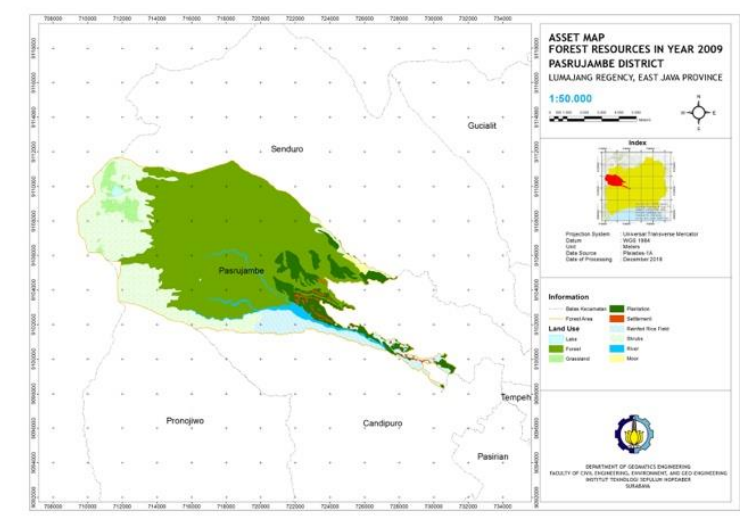

Figure 3. Asset Map of Forest Resources in Year 2009

b. The Liability of Forest Resources in 2017 Amount of forest resource utilization is stated in liabilities. The liability of forest resources in this study uses land use in year 2017 forest area based on object-based classification methods. The results of calculation of liability area can be seen in Table 4 . 
Table 4. Assets of Forest Resources in Year 2017

\begin{tabular}{|c|c|c|c|c|c|c|}
\hline No & $\begin{array}{c}\text { Land Use in } \\
\text { Year } \\
2017\end{array}$ & $\begin{array}{l}\text { Protected } \\
\text { Forest } \\
\text { (ha) }\end{array}$ & $\begin{array}{c}\text { Production } \\
\text { Forest } \\
\text { (ha) }\end{array}$ & $\begin{array}{c}\text { National } \\
\text { Park } \\
\text { (ha) }\end{array}$ & $\begin{array}{c}\text { Forest } \\
\text { Zone } \\
\text { (ha) }\end{array}$ & $\begin{array}{c}\text { Percentage } \\
\text { (\%) }\end{array}$ \\
\hline 1 & Lake & 0.00 & 0.00 & 28.77 & 28.77 & 0.23 \\
\hline 2 & Forest & 155.20 & 1027.91 & 6648.01 & 7831.12 & 63.18 \\
\hline 3 & Industry & 0.00 & 0.80 & 0.00 & 0.80 & 0.01 \\
\hline 4 & Grassland & 0.00 & 0.00 & 556.57 & 556.57 & 4.49 \\
\hline 5 & Plantation & 0.00 & 571.22 & 0.00 & 571.22 & 4.61 \\
\hline 6 & Settlement & 0.00 & 63.50 & 0.00 & 63.50 & 0.51 \\
\hline 7 & $\begin{array}{l}\text { Irrigates } \\
\text { Rice Field } \\
\text { Rainfed Rice }\end{array}$ & 0.00 & 182.16 & 0.00 & 182.16 & 1.47 \\
\hline 8 & Field & 0.00 & 738.91 & 1.04 & 739.95 & 5.97 \\
\hline 9 & Shrubs & 0.15 & 103.34 & 1786.5 & 1890.01 & 15.25 \\
\hline 10 & River & 0.00 & 173.14 & 40.93 & 214.07 & 1.73 \\
\hline \multirow[t]{2}{*}{11} & Moor & 31.00 & 245.48 & 40.26 & 316.74 & 2.56 \\
\hline & Total & 186.35 & 3106.45 & 9102.10 & 12394.90 & 100 \\
\hline
\end{tabular}

The liability used in this study uses land use in year 2017 as a result of object-based classification. The method was chosen because in this study emphasis was on object-based classification rather than digitizing on screen. This study also intend to see the results of application of object-based classifications to compile forest resource balances. The digitized on screen results are only used as a comparison and reference only. Liability proportion of Forestry Resources in Pasrujambe District presented in Figure 4.

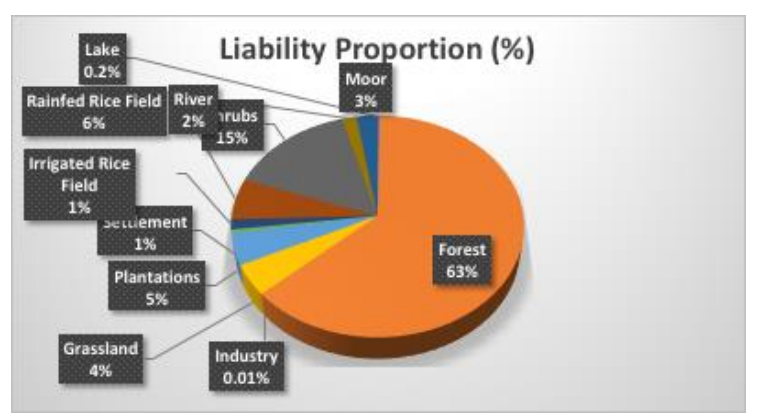

Figure 4. Liability Proportion of Forest Resources in Pasrujambe District in Year 2017

Land use in year 2017 (liability) within the forest area in Pasrujambe District was dominated by natural land use, such as bushes, rainfed rice fields and forests. The use of dominant agricultural land in forest areas, such as rainfed rice fields and the use of dominant cultivation land in forest areas are plantations, grasslands and moors. Rainfed rice fields and plantations are mostly located in production forest areas. The largest proportion of land use in year 2017 forest area in shrubs of 1890.01 $\mathrm{Ha}(15 \%)$ and the smallest area in the industry of $0.80 \mathrm{Ha}(0.01 \%)$. The area of forest itself is 7831.12 ha $(63 \%)$ of the total area. The result of liability of forest resources consist of 11 (eleven) land use classes.

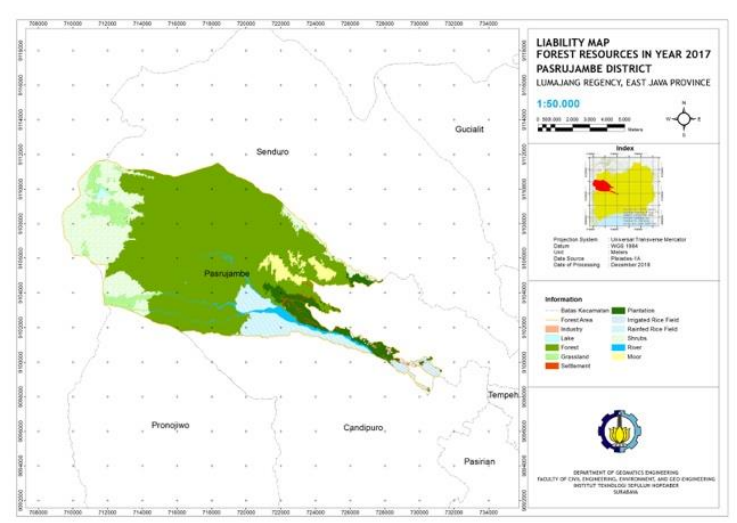

Figure 5. Liability Map of Forest Resources in Pasrujambe District in Year 2017

c. Forest Resource Balance Results

As we known the assets and liabilities of forest resources results, it is followed by calculating balance of land resources in forest area. the results were obtained as shown in Table 5 . 


\begin{tabular}{lccc}
\hline \multicolumn{1}{c}{ Land Use } & \multicolumn{2}{c}{ Forest Area (Ha) } & Changes \\
& $\begin{array}{c}\text { Year 2009 } \\
\text { (Assets) }\end{array}$ & $\begin{array}{c}\text { Year 2017 } \\
\text { (Liability) }\end{array}$ & (Ha) \\
\hline Lake & 29.27 & 28.77 & -0.50 \\
Forest & 7263.26 & 7831.12 & 567.86 \\
Industry & 0.00 & 0.80 & 0.80 \\
Grassland & 342.58 & 556.57 & 213.99 \\
Plantation & 947.36 & 571.22 & -376.15 \\
Settlement & 78.92 & 63.50 & -15.42 \\
Irrigated Rice Field & 0.00 & 182.16 & 182.16 \\
Rainfed Rice Field & 721.91 & 739.95 & 18.04 \\
Shrubs & 2734.35 & 1890.01 & -844.34 \\
River & 235.97 & 214.07 & -21.90 \\
Moor & 41.27 & 316.74 & 275.47 \\
\multicolumn{1}{c}{ Total } & $\mathbf{1 2 3 9 4 . 9 0}$ & $\mathbf{1 2 3 9 4 . 9 0}$ & \\
\hline
\end{tabular}

Changes in distribution and area of functions of land use in forest areas are presented in Table 6.

Table 6. Land Use Change

\begin{tabular}{|c|c|c|}
\hline \multicolumn{2}{|c|}{ Land Use } & \multirow[t]{2}{*}{ Area $(\mathrm{Ha})$} \\
\hline Year 2009 & Year 2016 & \\
\hline \multirow[b]{2}{*}{ Lake } & Forest & 0.81 \\
\hline & Grassland & 0.90 \\
\hline \multirow{8}{*}{ Forest } & Lake & 0.16 \\
\hline & Grassland & 1.10 \\
\hline & Settlement & 0.54 \\
\hline & Plantation & 39.79 \\
\hline & Rainfed Rice Field & 216.98 \\
\hline & Shrubs & 128.95 \\
\hline & River & 14.12 \\
\hline & Moor & 82.09 \\
\hline \multirow{6}{*}{ Grassland } & Lake & 0.44 \\
\hline & Forest & 0.31 \\
\hline & Plantation & 0.78 \\
\hline & Shrubs & 14.76 \\
\hline & River & 1.05 \\
\hline & Industry & 0.18 \\
\hline \multirow{7}{*}{ Plantation } & Forest & 199.95 \\
\hline & Settlement & 14.16 \\
\hline & Irrigated Rice Field & 50.39 \\
\hline & Rainfed Rice Field & 0.76 \\
\hline & Shrubs & 17.78 \\
\hline & River & 1.50 \\
\hline & Moor & 234.08 \\
\hline \multirow{4}{*}{ Settlement } & Forest & 5.06 \\
\hline & Plantation & 26.49 \\
\hline & Irrigated Rice Field & 4.65 \\
\hline & Rainfed Rice Field & 0.27 \\
\hline
\end{tabular}

\begin{tabular}{|c|c|c|}
\hline \multicolumn{2}{|c|}{ Land Use } & \multirow[t]{2}{*}{ Area $(\mathrm{Ha})$} \\
\hline Year 2009 & Year 2016 & \\
\hline & Moor & 0.50 \\
\hline \multirow{7}{*}{$\begin{array}{l}\text { Rainfed Rice } \\
\text { Field }\end{array}$} & Industry & 0.57 \\
\hline & Forest & 8.14 \\
\hline & Settlement & 6.03 \\
\hline & Plantation & 64.53 \\
\hline & Irrigated Rice Field & 127.11 \\
\hline & River & 6.09 \\
\hline & Lake & 0.61 \\
\hline \multirow{6}{*}{ Shrubs } & Forest & 782.77 \\
\hline & Grassland & 229.85 \\
\hline & Plantation & 1.36 \\
\hline & Rainfed Rice Field & 6.15 \\
\hline & River & 3.70 \\
\hline & Moor & 0.07 \\
\hline \multirow{6}{*}{ River } & Industry & 0.05 \\
\hline & Forest & 34.81 \\
\hline & Settlement & 0.81 \\
\hline & Plantation & 6.32 \\
\hline & Irrigated Rice Field & 0.02 \\
\hline & Rainfed Rice Field & 6.36 \\
\hline \multirow{3}{*}{ Moor } & Forest & 19.74 \\
\hline & Plantation & 3.37 \\
\hline & Shrubs & 18.16 \\
\hline Total & & 2385.17 \\
\hline
\end{tabular}

Land use changes in year 2009 and year 2016 in forest areas, such as expansion of forests, grasslands, moors, irrigated rice fields, rainfed rice fields, industry and reduced lakes, plantations, settlements, shrubs and rivers. Changes in land use classes increase in forests of $567.86 \mathrm{Ha}$, and land use classes decrease in 
shrubs of $844.34 \mathrm{Ha}$. Year by year, reduced area of land use within forest area, causing an increase in forest area itself. Within forest area there is a minimum area which must be maintained as a forest area amount $30 \%$ of land area to ensure the maximum benefit from the forest and based on the socio-economic needs of the community as well as various physical, hydrological and ecosystem factors (Ministry of Forestry and Plantation 1999). Land use in year 2009 consist of 9 (nine) classes only, while land use in year 2016 consist of 11 (eleven) classes. Because of the ability of each method, there is a difference in the distribution and extent of land use functions in forest area of the District of Pasrujambe. Changes in area of land use functions within forest areas are illustrated in Figure 6.

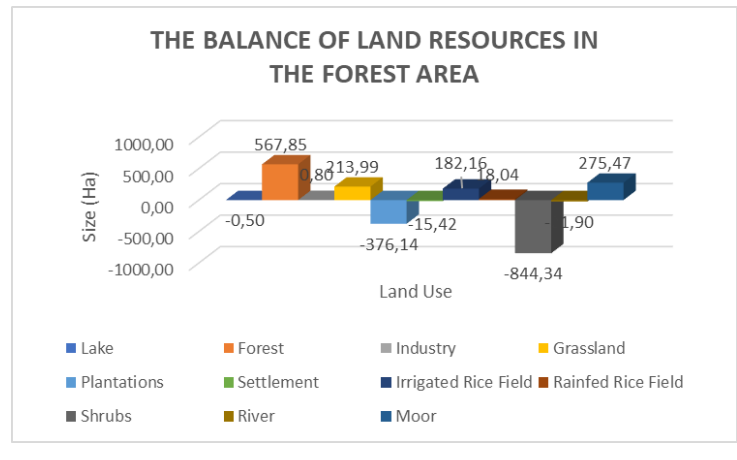

Figure 6. Chart of Land Resources Balance Within Forest Areas

The largest total area of land use classified as another land use class, such as shrubs of $1023.90 \mathrm{Ha}$, where shrubs is classified as forest. Based on the results of the forest resource balance, the forest area increased by $567.86 \mathrm{Ha}$

\section{CONCLUSION}

The result of this research indicate that the forest resource balance in year 2009 and year 2017, using land within forest areas in 2017, which consist of industries, plantations, agricultures, bushes, and settlement. The largest land use is increase of forests, grasslands, moor, irrigated rice fields, rainfed rice fields, industry and decrease of lakes, plantations, settlements, shrubs, and rivers. The proportion of land use assets in 2009 in largest forest area in shrubs of $2734.35 \mathrm{Ha}$ (22\%) and smallest area on moor of $41.27 \mathrm{Ha}$ $(0.33 \%)$, proportion of forest area is 7263.26 $\mathrm{Ha}(58.60 \%)$ of the total area. The largest proportion of land use in year 2017 forest area in shrubs of $1890.01 \mathrm{Ha} \mathrm{(15 \% )} \mathrm{and} \mathrm{the} \mathrm{smallest}$ area in the industry of $0.80 \mathrm{Ha}(0.01 \%)$. The area of forest itself is 7831.12 ha (63\%) of the total area. Changes in land use classes increase in forests of $567.86 \mathrm{Ha}$, and land use classes decrease in shrubs of $844.34 \mathrm{Ha}$.

\section{REFERENCES}

Agarwal, C., Green, G.L., Grove, J.M., Evans, T., and Schweik, C., 2000. A Review and Assessment of Land Use Change Models dynamics of space, time, and human choice. 4th International Conference on Integrating GIS and Environmental Modeling, Banff, Alberta Canada

Anderson, J. R., Hardy, E. E., Roach, J. T. dan Witmer, R.E. 1976. A Land Use and Land Cover Classification System For Use With Remote Sensor Data. Washington DC: USGS Professional Paper 964. A revision of the land use classification system as presented in the USGS circular 671

Baatz, M., Schape, A. 2000. Multiresolution Segmentation an Optimization Approach for High Quality Multiscale Image Segmentation. In: Strobl, Angewandte Geographische Informationsverabeitung XII. Wichmann, Heidelberg.

Demers, M. N., Fundamental of Geographic Information System, John Wiley\& Sons, Inc., New York, 1997.

Lilesand T. M. dan Kiefer, R. W. 1976. Fifth Edition : Remote Sensing and Image Intrepetation. United Stated America : UG/GCS Information Services, Inc.

Zhang, Y., Maxwell, T. 2006. AFuzzy Logic Approach to Supervised Segmentation for Object-Oriented Classification. ASPRS Annual Conference, Reno, Nevad, May 1-5, 2006. 